\title{
\#İşimisev(m)iyorum: Banka Sektöründe Çalışanların Online Yorumları Üzerine Bir İçerik Analizi ${ }^{1}$
}

DOI: $10.26466 /$ opus.642768

$*$

\author{
Berivan Tatar* - Büşra Müceldili** - Oya Erdil ${ }^{* * *}$ \\ * Araş Gör., Gebze Teknik Üniversitesi, İşletme Fakültesi, Gebze/ Kocaeli/ Türkiye \\ E-Posta: btatar@gtu.edu.tr \\ ORCID: 0000-0002-0934-3734 \\ ** Dr. Öğr. Üyesi, Gebze Teknik Üniversitesi, İşletme Fakültesi, Gebze/ Kocaeli/ Türkiye \\ E-Posta: bmuceldili@gtu.edu.tr ORCID: 0000-0003-2770-6137 \\ *** Prof. Dr. Gebze Teknik Üniversitesi, İşletme Fakültesi, Gebze/ Kocaeli/ Türkiye \\ E-Posta: erdil@gtu.edu.tr \\ ORCID: 0000-0003-3793-001X
}

\section{Öz}

Son yillarda internet kullanımının yaygınlaşmasıyla birlikte çalı̧anların kurumlarındaki deneyimlerini, memnuniyet ve memnuniyetsizliğini dile getirebilecekleri mecralar, geleneksel iletişim kanallarnndan sosyal medya kanallarına kaymıştır. Özellikle bu mecralardaki memnuniyetsizlik yorumları, çalışanları kurumlarından ayrılmaya iten sebepleri anlayabilme imkânı sunması ve geniş bir kitleye ulaşma ihtimali göz önünde bulundurulduğunda potansiyel çalşanların kuruma dair algılarmı etkileyebilmesi sebebiyle büyük öneme sahiptir. Bu bağlamda bu çalışmanın amacl, çalışanların kurumlarına dair görüşlerini paylaştıkları bir web sitesi olan Indeed.com'da yer alan memnuniyetsizlik yorumlarmı inceleyerek kurumlar için genel bir bakış sunmaktadır. Araștırma kapsamında Indeed.com web sitesinde yer alan, 19 bankanın çalışanları tarafindan yapılan 484 yorum ikincil veri olarak kullanılmış ve MAXQDA 18.0 aracilığılala içerik analizine tabi tutulmuştur. Araştırma bulguları ışığında bankacıllk sektörü çalışanlarının ücret ve yan haklar, iş ilişkileri, çalı̧ma koşulları, çalışma saatleri, örgütsel faktörler, psikolojik faktörler ve iş ile ilgili çeşitli faktörlerden memnuniyetsizlik duyduğu belirlenmiştir. Bunun yanı sıra, satış ve hedef baskısının olması, iş yükünün fazla olması ve iş stresinin fazla olması en fazla memnuniyetsizlik yaratan unsurlar arasinda yer almaktadır.

Anahtar Kelimeler: İş Tatmini, İş Tatminsizliği, Çalışan Sesliliği, Ağızdan Ağıza İletişim, İş ile

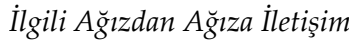

\footnotetext{
${ }^{1}$ Bu çalışma, 4-6 Eylül 2019 tarihleri arasında düzenlenen 2. BOR Conference'da sunulan bildiri genişletilerek hazırlanmıştır
} 


\title{
\#I(dont)lovemyjob: A Content Analysis On Online Reviews of Employees in the Banking Sector
}

\begin{abstract}
With the widespread use of the internet in recent years, the places where employees can express their work experiences, satisfaction and dissatisfaction about their organizations have shifted from traditional communication channels to social media channels. In particular, dissatisfaction reviews in these channels are of great importance as they provide an opportunity to understand the reasons that force employees to leave their organizations and affect the perceptions of potential employees. In this context, the purpose of this study is to provide an overview to organizations by examining the employees' dissatisfaction reviews on Indeed.com, a website where employees share their views on their organizations. 484 reviews on Indeed.com made by the employees of 19 banks were used as secondary data and subjected to content analysis via MAXQDA 18.0. In the light of employee reviews within the scope of the research, it was determined that the banking sector employees were dissatisfied with various factors related to wages and benefits, working relationships, working conditions, working hours, organizational factors, psychological factors, and job-related factors. Besides, most dissatisfying factors were sales and target pressure, high workload, high work, and stress..
\end{abstract}

Keywords: Job Satisfaction, Job Dissatisfaction, Employee Voice, Word of Mouth, Job-related Word of Mouth 


\section{Giriş}

İnternet kullanımın yaygınlaşması ile birlikte çalışanlar yeni iletişim kanalları ile kurumlarına dair bilgileri paylaşma imkânı bulmuştur. Sosyal medya kanallarının yanı sıra işveren değerlendirme siteleri de çalışanlara fikir, görüş ve sıkıntılarını paylaşabilecekleri yeni bir ortam sunmuştur. Kurum içerisindeki geleneksel iletişim kanallarını kullanarak çalışanların problemli gördükleri noktaları paylaşmalarının, işten atılma korkusu gibi sebeplerle tercih edilmediği ve bu durumda genelde çalışanların sessiz kalmayı tercih ettiği bilinmektedir (Morrison, 2014, s.180-184). Geleneksel iletişim kanallarının aksine elektronik ortamda yapılan ağızdan ağıza iletişimde kullanılan bloglar, işveren değerlendirme siteleri ve sosyal ağlarda anonim olarak paylaşım yapılabilme imkânı sunmakta ve geleneksel ağızdan ağıza iletişimde duyulan kaygıyı azaltması sebebiyle çalışanlar tarafından daha fazla tercih edilebilmektedir.

Çalışanların bu mecralarda yaptıkları paylaşımlar, sosyal medya sitelerinin milyarlarca kullanıcıya sahip olması dolayısıyla tahmin edilenden daha geniş kitlelere ulaşma potansiyeline sahiptir. We Are Social ve Hootsuite işbirliği ile hazırlanan "Digital in 2019" raporuna göre Temmuz ayı itibariyle dünya nüfusunun \%56'sı İnternet kullanıcısıyken, dünya nüfusunun $\% 45^{\prime} \mathrm{i}$ sosyal medya kullanıcısıdır. Türkiye açısından değerlendirildiğinde ise nüfusun \%72'si İnternet kullanıcisıyken, nüfusun \%63'ünün aktif sosyal medya kullanıcısı olduğu görülmektedir (Kemp, 2019). Kullanıcı oranlarının bu kadar yüksek olduğu bu mecralarda bilginin paylaşımı ve yayılımı da hızlı olmaktadır. Bu mecralarda yer alan bireylerin tüketici kimlikleriyle ürün ve hizmet deneyimlerini paylaşabildikleri gibi çalışan kimlikleriyle de kurumları içerindeki deneyimleri ile ilgili bilgi paylaşımında bulunması muhtemeldir. Bu açıdan değerlendirildiğinde kurumlar için sadece ürettikleri ürünler ve sundukları hizmet açısından değil, sundukları çalışma deneyimi ve örgütsel çekicilik için de sosyal medya önemli bir mecra haline gelmiştir.

Bunun yanı sıra, çalışanların sosyal mecralarda kurumlarına dair yaptıkları paylaşımların, potansiyel çalışanların kurumsal imaj algısını etkilediği ve bu adayların işe başvurma niyeti üzerinde etkili olduğu belirlenmiştir (Van Hoye ve Lievens, 2009, s.349). Mevcut çalışanlar açısından değerlendirildiğinde ise; paylaşılan mesajların içeriği çalışanlarının memnun olduğu ve ol- 
madığı noktaları anlamada kurumlara yardımcı olabilecek önemli bir kaynaktır. Bu bağlamda kurumların işten ayrılma niyeti gibi olumsuz sonuçlara varmadan çalışanların sosyal medya mecralarında yapmış oldukları memnuniyetsizliğe yönelik paylaşımları takip etmesi ve bu memnuniyetsizliklerin giderilmesine yönelik aksiyonlar alması gerekmektedir (Keeling, McGoldrick ve Sadhu 2013, s.100).

Ancak pazarlama alanında geniş bir alan yazına sahip olan ağızdan ağıza iletişim kavramının, yönetim alan yazını ve çalışanlar perspektifinde kısıtlı kaldığı görülmektedir. Özellikle işle ilgili ağızdan ağıza iletişim alanında yapılan çalışmaların (Van Hoye ve Lievens, 2009, s.341) ve sosyal ağlardaki çalışan ağızdan ağıza iletişimi hakkında bilinenlerin ve araştırmaların (Keeling, McGoldrick ve Sadhu, 2013, s.100) sinırlı olduğu görülmektedir. Bu bağlamda bu çalışmanın amacı; devir oranlarının yüksek olduğu bankacılık sektörü çalışanların memnuniyetsizlik duyduğu hususları Indeed.com web sitesinden alınan ikincil veriler üzerinden belirleyerek kurumlar için genel bir bakış sunmaktır.

\section{Kavramsal Çerçeve}

\section{İş Tatminsizliğ $i$}

İş tatminsizliği “İnsanların kişisel ve örgütsel ihtiyaçlarını karşılamada işlerini yetersiz kaldığının farkına varmaları sebebiyle işlerine karşı gösterdikleri olumsuz bir tutum" olarak tanımlanmıştır (Wandelt, Pierce ve Windowson, 1981, s.72). Öte yandan iş tatmini; örgütsel bağl1lık (Lam ve Qiu Zhang, 2003, s.216; Silva, 2006, s.324), performans (Iaffaldano ve Muchinsky, 1985) ve işten ayrılma niyeti (Griffeth, Hom, ve Gaertner, 2000) gibi çalışan davranışı üzerindeki etkileri sebebiyle insan kaynakları alan yazınında önemle üzerinde durulan bir kavramdır. Çalışanların işlerinden tatmin olmaları; kurumlar tarafından arzu edilen bu çalışan davranışlarını olumlu etkilerken, iş tatminsizliğinin yüksek olması durumunda ise çalışan davranışları olumsuz etkilenecektir. Bu sebeple çalışanların iş tatmini kadar tatminsizlikleri ve bunun altında yatan nedenlerin anlaşılması kurumlar açısından oldukça önemlidir.

Hirschman (1970), çalışanların iş doyumsuzluğu yaşadıkları durumda "Çıkış, Konuşma ve Sadakat" olmak üzere üç farklı tepki gösterdiklerinden 
bahsetmiştir. Çıkış durumunda çalışanlar, doyumsuzluk yaşadıkları durumda tatminsizliklerinin altında yatan problemleri çözmek yerine kurumlarından ayrılmayı tercih etmektedir. Konuşma durumunda çalışanlar, problemlerin çözümü için kurum içerisindeki yetkili bireylere ilgili sorunları dillendirmeyi seçerek çözüm arayışında olmaktadır. Son olarak sadakat durumunda ise çalışanlar, genellikle sorunları görmezden gelerek ne konuşma tepkisi esnasında gösterdikleri problemi çözmeye yönelik çabayı ne de çıkış durumunda verdikleri işten ayrılma tepkisini vermemektedir.

Bu çalışma kapsamında çalışanların tatminsizlik durumunda verdikleri tepkilerden biri olan "Konuşma” üzerine odaklanılmıştır. Bu bağlamda çal1şanların konuşma tepkisine karşılık gelen çalışan sesliliği kavramı son yıllarda araştırmacıların ilgisini çekmiştir. Çalışan sesliliği genel olarak çalışanların kurumlarına dair fikirlerini, önerilerini ve fark ettikleri problemleri formel iletişim mekanizmaları aracılığıyla kurumlarıyla paylaşmalarını ifade etmektedir (Morrison, 2014, s.179). Bu bağlamda çalışanlar, öneri-odaklı seslilik, problem odaklı seslilik ve fikir odaklı seslilik davranışı olmak üzere üç farklı davranış gösterebilmektedir (Morrison, 2014, s.174). Öneri odaklı seslilik, çalışanların kurum içerisindeki bir süreç, birim ya da doğrudan kurumun kendisinde iyileştirmeyi beraberinde getirebilecek önerilerini ilgili kişilerle paylaşmasını içerirken, görüş odaklı seslilik ise çalışanların fikirlerini kurumla paylaşmasıdır. Öte yandan problem odaklı seslilik ise çalışanların kurumlarına zarar verebileceğini ve doğru olmadığını düşündükleri faaliyetler ve durumlarla ilgili görüş beyan etmesidir.

Seslilik, her ne kadar kurumlar tarafından önemsenen ve teşvik edilen bir çalışan davranışı olsa da seslilik davranışını sergilemek çalışanlar açısından pek de kolay olmamaktadır. Çalışanlar, özellikle kurum içerindeki sorunları dillendirdiklerinde sürekli şikâyet eden biri olarak algılanmaktan, kurum içerisindeki yöneticilerin desteğini ve saygısını kaybetmekten korkabilmektedir. Bunun yanı sıra çalışanlar, görüşlerini veya kaygılarını paylaşmanın; istemedikleri görevler verilmesi, terfi almalarının engellenmesi, işten çıkarılmaları ya da başkalarının olumsuz sonuçlara maruz kalması gibi olumsuz durumlara neden olacağından endişe duyabilmektedir (Milliken, Morrison ve Hewlin 2003, s.1462). Bu kaygı ve endişeler çalışanları kurum içerisindeki formel kanalları kullanarak seslilik davranışı göstermeleri yerine, daha informel iletişim kanallarına yönlendirmektedir. 
Bu noktada sosyal medya kullanımı ve kanallarının yaygınlaşması, çalışanların seslilik davranışı ile paylaşacakları görüş, öneri ve problemleri paylaşabilecekleri ve seslilik davranışı gösterdiklerinde duydukları kaygıyı azaltabilecek yeni bir iletişim kanalı sunmuştur. Bu yeni iletişim kanalları anonim olarak gönderi paylaşımına izin vermesi sebebiyle çalışanlara herhangi bir endişe ve kaygı duymadan fikirlerini paylaşabilme özgürlüğünü de sunmuştur. Bu durum yönetim ve insan kaynakları alanında çalışan araştırmacıların ilgisini çekmiş ve alan yazına da yeni kavramlar kazandırmıştır. İşle İlgili Ağızdan Ağıza İletişim ve Çalışan Ağızdan Ağıza İletişimi bu kavramlar arasindadır.

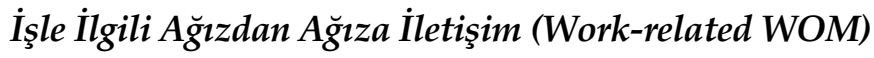

İşle ilgili Ağızdan Ağıza İletişim (Work-related WOM), bireyler arasında bir kuruluş hakkında veya belirli işler hakkında yapılan bilgi alışverişi olarak tanımlanmıştır (Van Hoye ve Lievens 2009, s.343). İşle ilgili Ağızdan Ağıza İletişimle iletilen mesajların içeriği, işin özellikleri, kurumsal deneyim ve çalışma ortamı ile ilgili olması sebebiyle, insan kaynakları bağlamında kurumsal imaj algısının oluşumunda önemli bir unsurdur (Melián-González ve Bulchand-Gidumal 2016, s.711).

Pazarlama alan yazınında yer alan ağızdan ağıza iletişimle benzer olarak işle ilgili ağızdan ağıza iletişim, ifade edilme biçimine bağlı olarak internet üzerinden ya da yüz yüze gerçekleştirilebilmektedir. Çalışanların internet aracılığıyla kurumlarına dair fikirlerini paylaşması "Elektronik ortamda yapılan işle ilgili ağızdan ağıza iletişim (weWOM)" olarak adlandırılmış olup, çalışanların kullandıkları bu iletişim yoluna temelde işveren değerlendirme web siteleri aracllık ettiği görülmektedir (Melián-González ve Bulchand-Gidumal 2016, s.711). Pazarlama alanında tüketicilerin ziyaret ettikleri yerlerle ilgili görüşlerini paylaştıkları "TripAdvisor" gibi web siteleri ile benzer amaçla kurulan işveren değerlendirme siteleri de mevcuttur. Monster.com, Glassdoor, Workopolis.com, Indeed.com, Idealist.org" bu amaçla kurulan web sitelerinden bazılarıdır.

Çalışanların bu siteler üzerinden işverenleri ve işleri hakkındaki bilgileri paylaşması, bu bilgilerin özellikle potansiyel çalışanlara ulaşması açısından önemlidir. Çalışanların paylaştıkları her bilgi, potansiyel çalışan adaylarının 
kuruma dair sahip oldukları imaj algısını etkileyecek ve örgütsel çekicilik algilarında belirleyici olacaktır (Van Hoye ve Lievens 2009, s.344). Keeling, McGoldrick ve Sadhu (2013) yürüttükleri çalışmada işle ilgili olumlu ve olumsuz ağızdan ağıza iletişimin etkisini incelemiştir. Çalışma bulgularına göre işle ilgili ağızdan ağıza iletişimle paylaşılan olumsuz mesajlar, potansiyel çalışan adayları üzerinde olumlu olanlardan daha güçlü bir etkiye sahip olduğu belirlenmiştir. Benzer şekilde Van Hoye ve Lievens (2009, s.349) pozitif ağızdan ağıza iletişimin örgütsel çekicilik ve potansiyel adayların işe başvurma niyeti üzerinde olumlu etkileri olduğunu bulgulamıştır. Bu bulgular ışığında, internet ortamında yer alan olumsuz çalışan yorumları kurumlar açısından değerlendirilmesi gereken bir husus olarak belirmektedir.

\section{Çalışan Ăğızdan Ăğıza İletişimi (Staff Word-of-Mouth (SWOM))}

Çalışan Ağızdan Ağıza İletişimi (SWOM); çalışanların veya eski çalışanların, sosyal ağlarda kurumları hakkında bilgi ve görüşlerini paylaşmasını içeren bir süreçtir (Keeling, McGoldrick ve Sadhu 2013, s.89). İşle ilgili ağızdan ağıza iletişim yüz yüze ya da internet üzerinden yapılabilirken, Çalışan Ağızdan Ağıza İletişimi sadece sosyal ağlarda yapılan ağızdan ağıza iletişimi içermektedir.

Kurum içerisinde verilen ödüller, alınan başarılardan duyulan gurur ve kurum üyeleri tarafından tanınma, çalışanları pozitif ağızdan ağıza iletişime yöneltirken; adalet ve destek kavramlarının ihlali ile zayıflayan kurum kültürü ve iş ilişkileri çalışanları negatif ağızdan ağıza iletişime yöneltmektedir. Bunun yanı sıra kuruma duyulan yüksek örgütsel bağlılık ve kurumu destekleme isteği de benzer şekilde çalışanları ağızdan ağıza iletişime yönlendirmektedir (Keeling, McGoldrick, Charavitsidou ve Thompson, 2015, s.378).

Öte yandan potansiyel çalışan adayları, mevcut çalışanların kurumlarına dair paylaştıkları görüşleri, kurumsal reklam ve tanıtım faaliyetleri aracıl1ğıyla paylaşılan bilgilerden daha güvenilir görmektedir (Keeling, McGoldrick ve Sadhu 2013, s.90). Bu bağlamda kurumların sosyal ağlarda çalışanlarının neler paylaştığını takip etmesi, sosyal ağlarda yer alan negatif mesajların nedenlerini belirlemeye çalışması, pozitif mesajları arttırabilmek için çalışan memnuniyetini arttırmaya yönelik faaliyetler yürütmesi gerekmektedir (Keeling, McGoldrick ve Sadhu 2013, s.100). 


\section{Araştırma Metodolojisi}

$\mathrm{Bu}$ çalışma kapsamında çalışanların kurumlarına dair memnuniyetsizlik duydukları hususları belirlemek amaçlanmıştır. Bu amaç doğrultusunda aşağıdaki araştırma sorularının cevaplanması beklenmektedir:

1. Bankacılık sektörü çalışanlarında memnuniyetsizlik yaratan hususlar nelerdir?

2. Kamu ve özel sektör çalışanlarının memnuniyetsizlik duyduğu hususlarda bir farklılık var midır?

Indeed.com sitesi üzerinde yer alan çalışan yorumları ikincil veri olarak kullanılmıştır. Indeed.com 60'tan fazla ülkede 28 dilde kullanıma sunulan, 150 milyon şirket değerlendirmesi ve 600 milyon maaş bilgisini içeren bir web sitesidir. Indded.com çalışanların kurumlarındaki deneyimlerini anonim olarak paylaşabildikleri bir web sitesidir. Çalışanlar yalnızca deneyimlerini paylaşmakla kalmayıp, bu deneyimleri 1 ve 5 yıldız arasında derecelendirmektedir. Bunun yanı sıra çalışanlar, İş / Sosyal hayat Dengesi, Maaş/Avantajlar, İş Güvencesi/Yükselme, Yönetim, Kültür/Değerler kriterleri bağlamında kurumlarını değerlendirmektedir.

Bu çalışma kapsamında Indeed.com üzerinde yer alan 19 bankanın çalışanları tarafından yapılan 613 yorum, içerik analizine tabi tutulmuştur. $\mathrm{Bu}$ yorumlardan 120 tanesi çalışmaya konu olan bankalarda stajyer pozisyonunda çalışmış olan bireyler tarafından yapılmıştır. Yorum yapan stajyerlerin deneyim sürelerinin bilinmemesi sebebiyle kurum hakkında değerlendirme yapabilecek düzeyde deneyime sahip olamayacakları düşünülmüş ve bu yorumlar çalışmaya dâhil edilmemiştir. Sonuç olarak 2012- 2019 yılları arasında yapılan, toplamda 484 yorum üzerinden içerik analizi gerçekleştirilmiştir.

Temaların belirlenmesinde Conway vd. (2019, s.7) tarafından yürütülen çalışma esas alınmış, bu çalışmada yer alan temalara ek olarak psikolojik ve örgütsel faktörler temaları ortaya çıkmıştır. Araştırma yanlılığını azaltmak amaciyla kodlama sürecinde tüm araştırmacilar yorumlar üzerinden ayrı ayrı kod listelerini oluşturmuş ve daha sonrasında bir araya gelerek benzerlik ve farklılık gösteren kodlar üzerinde tartışarak nihai kod listesini oluşturmuşlardır. Kodlama sürecinin sonunda Sonuç olarak 7 ana tema ve 25 alt tema ortaya konmuş ve toplamda 495 kodlama yapılmıştır. 
Nicel araştırmalarda yer verilen geçerlilik ve güvenilirliğin aksine, nitel çalışmalarda İnandırıcılık üzerinde durulmaktadır ve İnandırıcılığın sağlanması için "İnanılırlık, Güvenilebilirlik, Doğrulanabilirlik ve Aktarılabilirlik" olmak üzere dört temel kriter belirlenmiştir (Guba ve Lincoln, 1982, s.246249). Bu çalışma kapsamında içsel tutarlılığa karşılık gelen İnanılırlık kriterinin sağlanması için Araştırmacı Üçgenleme yöntemi kullanılarak verilerin derlenmesi, analizi ve değerlendirilmesi aşamasında birden fazla araştırmacının yer alması sağlanarak araştırmacı önyargıları azaltılmaya çalışılmıştır. Bunun yanı sıra başvuru kaynaklarının yeterliliği (Referential adequacy materials) için çalışmaya konu olan verilerin işlenmemiş (ham) hali de gelecek çalışmalara katkıda bulunması düşüncesiyle saklanmıştır.

Dışsal geçerliliği sağlamak amacıyla, elde edilen bulguların evreni temsil edebilme gücünü ifade eden Aktarlabilirlik kriteri gözetilmiştir (Guba ve Lincoln 1982, s.246-249). Bu bağlamda evreni temsil edebilmek amaciyla, Indeed.com üzerinde yer alan ve 19 bankanın çalışanları tarafından 2012- 2019 yılları arasında yapılan tüm yorumlar çalışmaya dâhil edilmiştir. Elde edilen bulguların yönetim ve örgütsel davranış alanyazının yanı sıra bankacılık sektöründe yapılan çalışmalara ve örgüt psikolojisi alanında yapılan çalışmalara da aktarllabilmesi beklenmektedir.

Öte yandan Güvenilebilirlik bağlamında araştırma yöntemleri ve süreci ayrıntılı olarak aktarılmaya çalışılmıştır. Elde edilen veriler MAXQDA 18.0 programında analiz edilmesiyle çalışmanın güvenilebilirliği arttırılmaya çalışılmıştır. Bunun yanı sıra online platformlarda yer alan yorumların tarafsızlığı ve güvenilirliği de bir tartışma konusudur (Goes, Lin ve Au Yeung, 2014). Bu platformlarda yer alan yorumların anonim şekilde paylaşılması, sahte hesaplar tarafından gerçek dışı yorumların yapılmasına da imkân tanımaktadır (Luca ve Zervas, 2016). Bu doğrultuda, bu çalışma kapsamında ele alınan çalışan yorumlarının bahsi geçen kurumların çalışanları tarafından yapıldığı ön kabulüne dayanarak gerekli analizler gerçekleştirilmiştir. Bunun yanı sıra Alrubaian vd. (2018) online platformlarda yer alan verilerinin güvenilirliğinin değerlendirilmesinde bazı metotlara değinmiştir. Bu metotlardan gönderi düzeyinde güvenilirlik değerlendirmesi, mevcut çalışmanın kapsamına uygun olan bir yöntemdir. Bu bağlamda, paylaşılan gönderinin özellikleri, uzunluğu ve kullanılan kelimeler gönderinin güvenilirliği hakkında fikir vermektedir. Bu doğrultuda kısa ve çok genel değerlendirmeleri içeren çalışan 
yorumları çalışma kapsamına dâhil edilmemiştir. Öte yandan ortalama değerlendirme puanlarından çok farklı olan değerlendirmeler, sahte yorumların belirlenmesi için önerilen bir diğer yöntemdir (Keates, 2007; O'connor, 2010). Bu bağlamda çalışma kapsamında sadece memnuniyetsizlik içereceği düşünülen 1 ve 2 yıldız gibi düşük değerlendirmeler değil, diğer değerlendirmeler de gözden geçirilerek ortalama puanlamalardan çok fazla sapan değerlendirmeler çalışmaya dâhil edilmemiştir.

Son olarak nicel araştırmalarda nesnellik kriterine karşılık gelen Doğrulanabilirliğin sağlanması için araştırmada doğrudan alıntılara yer verilmiştir. Bunu yanı sıra, ham veriler ve işlenmiş veriler saklanmış, araştırma bulguları detaylı bir şekilde paylaşılmıştır.

\section{Araştırma Örneklemi}

Araştırma evrenini Türkiye'deki bankalar oluşturmaktadır. Bankacılık Düzenleme ve Denetleme Kurumu verilerine göre Türkiye'de faaliyet gösteren banka sayısı 38 olmakla birlikte, araştırmamızın örneklemi Indeed.com üzerinde çalışanların yorum yaptığ 19 bankadan oluşmaktadır. Yorumların anonim olarak paylaşılması sebebiyle katılımcıların yaş, cinsiyet ve benzeri özellikleri bağlamındaki bilgilere ulaşılamamıştır.

Katılımc yorumlarının demografik özellikleri Tablo 1'de sunulmuştur. Buna göre yorumların ağırlıklı olarak 2016-2017 (\%47,1) yılında yapıldığı görülmektedir.

Yorumların bankalara göre dağılımı göz önünde bulundurulduğunda; yorum yapan katılımcların çoğunluğu Denizbank (\%14,9) ve Akbank $(\% 19,8)$ çalışanıdır. Kamu ve özel sektör olarak değerlendirildiğinde ise yorumların \%93 ‘̈ kamu sektöründe yer alan bankacılık sektörü çalışanları tarafından yapılırken, özel sektör bankacılık sektörü çalışanları tarafından yapılan yorumlar \%7 oranındadır. Öte yandan katılımcılar ağırlıklı olarak yönetici (\%14) ve satış temsilcisi (\%19) pozisyonunda çalışmaktadır 
\#İşimisev(m)iyorum: Banka Sektöründe Çalışanların Online Yorumları Üzerine Bir İçerik Analizi

Tablo 1. Katılımcı yorumlarnın demografik özellikleri

\begin{tabular}{|c|c|c|c|}
\hline Değişkenler & & $\mathbf{F}$ & $\%$ \\
\hline \multirow[t]{4}{*}{ Yorumların yıllara göre dağılımı } & $2012-2013$ & 19 & 3,9 \\
\hline & 2014-2015 & 56 & 11,6 \\
\hline & 2016-2017 & 228 & 47,1 \\
\hline & 2018-2019 & 181 & 37,4 \\
\hline \multirow{19}{*}{$\begin{array}{l}\text { Yorumların bankalara göre } \\
\text { dağılımı }\end{array}$} & Albaraka Türk & 2 & 0,4 \\
\hline & Societe Generale S.A. & 5 & 1,0 \\
\hline & Türkiye Finans & 6 & 1,2 \\
\hline & Şekerbank & 7 & 1,4 \\
\hline & Odea Bank & 8 & 1,7 \\
\hline & Vakıflar Bankası & 10 & 2,1 \\
\hline & Anadolubank & 8 & 1,7 \\
\hline & QNB Finansbank & 17 & 3,5 \\
\hline & Kuveyt Türk Katılım Bankası & 17 & 3,5 \\
\hline & Halk Bankası & 18 & 3,7 \\
\hline & Ziraat Bankası & 20 & 4,1 \\
\hline & Türk Ekonomi Bankası & 21 & 4,3 \\
\hline & İş Bankası & 23 & 4,8 \\
\hline & Yapı Ve Kredi Bankası & 25 & 5,2 \\
\hline & HSBC Bank & 33 & 6,8 \\
\hline & ING Bank & 37 & 7,6 \\
\hline & Garanti Bankası & 59 & 12,2 \\
\hline & Denizbank & 72 & 14,9 \\
\hline & Akbank & 96 & 19,8 \\
\hline \multirow{10}{*}{$\begin{array}{l}\text { Katılımciların pozisyonlara } \\
\text { göre dağılımı }\end{array}$} & Müdür/ Müdür yardımcısı & 37 & 8 \\
\hline & Analist & 12 & 2 \\
\hline & Uzman yardımcısı & 18 & 4 \\
\hline & Memur & 22 & 5 \\
\hline & Uzman & 33 & 7 \\
\hline & Yönetmen & 36 & 7 \\
\hline & Operasyon yetkilisi & 40 & 8 \\
\hline & Yönetici & 69 & 14 \\
\hline & Satış temsilcisi & 94 & 19 \\
\hline & Diğer & 123 & 25 \\
\hline
\end{tabular}

\section{Araştırma Bulgulanı}

484 yorum üzerinden yapılan içerik analizi sonucunda 495 kodlama yapılmış, 7 ana tema ve 25 alt tema ortaya konmuştur. Ana ve alt temalara ilişkin bilgiler Tablo 2' de sunulmuştur. 
Tablo 2. Çalışmanın Ana ve Alt Temalar

\begin{tabular}{|c|c|}
\hline Ana Temalar & Alt Temalar \\
\hline \multirow[t]{5}{*}{ Örgütsel Faktörler } & Kurumsallı̆̆ın Zayıf Olması \\
\hline & Yönetim Tarzı Ve Yaklaşımı \\
\hline & Etik Değerlerin Gözetilmemesi \\
\hline & Örgütsel Adaletin Zayıf Olması \\
\hline & Bürokrasinin Fazla Olması \\
\hline \multirow[t]{7}{*}{ İş ile İlgili Faktörler } & Terfi İmkânının Olmaması \\
\hline & İş Yükünün Fazla Olması \\
\hline & Performans Değerlendirme Sistemindeki Problemler \\
\hline & Hedef Ve Satış Baskısının Olması \\
\hline & İş Yaşam Dengesi \\
\hline & Kariyer Geliştirme Ve Eğitim İmkânlarının Yetersizliği \\
\hline & Esnek Çalısmaya İzin Vermeme \\
\hline \multirow[t]{3}{*}{ Psikolojik Faktörler } & İş Stresinin Fazla Olması \\
\hline & Mobbing \\
\hline & Çalışanlara Değer Verilmemesi \\
\hline \multirow{3}{*}{ Çalışma Koşulları } & Fiziksel Ortam Yetersizliği \\
\hline & Çalışma Ortamı \\
\hline & İş Yerinin Lokasyon Olarak Uzaklığı \\
\hline \multirow[t]{4}{*}{ Ücret ve Yan Haklar } & Alınan Ücretin Yetersizliği \\
\hline & Prim, Mesai Ücretleri Gibi Ödemelerdeki Problemler \\
\hline & Maaşlara Yapılan Zammın Yetersizliği \\
\hline & Yan Hakların Azlığı \\
\hline \multirow[t]{3}{*}{ Çalışma Hayatındaki İlişkiler } & İş Arkadaşları Ile Olan İlişkiler \\
\hline & Yöneticilerin Çalışanlarla İlişkileri \\
\hline & Müşterilerle İlişkiler \\
\hline Çalışma Saatlerinin Fazlalığı & \\
\hline
\end{tabular}

Elde edilen veriler ışığında, bankacılık sektörü çalışanlarının örgütsel faktörler, iş ile ilgili faktörler, psikolojik faktörler, çalışma koşulları, ücret ve yan haklar, iş ilişkileri ve çalışma saatlerinin fazlalığı hususunda memnuniyetsizlik duyduğu belirlenmiştir.

\section{Çalışanlarda İş Tatminsizliği Yaratan Faktörler}

Çalışanlarda İş Tatminsizliği Yaratan Örgütsel Faktörler: Örgütsel faktörler açısından değerlendirildiğinde çalışanların; yönetim tarzı ve yaklaşımındaki problemler, kurumsallığın zayıf olması, etik değerlerin gözetilmemesi, örgütsel adaletin zayıf olması ve bürokrasinin fazla olması noktasında memnuniyetsizlik yaşadığı belirlenmiştir. Çalışanların özellikle yetkin olmayan yöneticilerin mevcut olması, yönetimin zayıf olması ve objektif bir biçimde ger- 
çekleştirilmemesi noktasında kurum içerisindeki yönetim tarzı ve yaklaşımından memnun olmadığı görülmüştür. Bu duruma ilişkin katılımcı yorumu şu şekildedir:

- "Sektörün bir adım gerisinden gelen ve üst yönetimin piyasayı iyi okuyamadığı için yaptı̆̆ı hataları ve yönetimce atılan yanlış adımlarm faturasımı çalışanlarma çıkaran, müşteri memnuniyetinin sadece çalışanlarm işi olduğunu sanarak üst yönetim tarafindan kısa vadeli politikalarla kar tutturmaya çallşan demode bir banka." (Akbank Çalı̧̧anı, Yönetici, 2016)

Öte yandan çalışanların Kurumsallığın Zayıf Olması alt temasında; genel olarak bankanın yeni kurulmuş olması, bankanın müşteri gözündeki itibarının zayıf olması ve kurum kültürünün oturmamış olmasına yönelik memnuniyetsizlik ifade ettikleri görülmüştür. Benzer şekilde etik değerlerin kurum içerisinde önemsenmediğine ilişkin katılımcı yorumuna aşağı̆da yer verilmiştir:

- "Dönem dönem iç memnuniyet anketleri olur. Sadece çalışanın bireysel olarak doldurması gereken, sakl kalacak anketler. Anket zamanı en üstteki altındakilere baskı yapar olumsuz bir şey yazılmasın diye. Anketleri çoğu zaman yetkiliniz sizin bilgisayara oturup kendisi doldurur. Oysa tamamen etik dişdır. Hoş etik olan pek bir şey bulamazsını. " (Garanti Bankası Çalışanı, Asis$\tan , 2018)$

Bürokrasi noktasında genel olarak ast-üst ilişkilerinin çok katı olduğu ve açı iletişimin mümkün olmadığından bahsedilmiştir. Örneğin; Akbank çal1şanının ifadesi şu şekildedir: "Ast ve üst yönetim arasında uçurum bulunan, askeri disipline dayah bürokratik bir kurum"( Akbank Çalışanı, Yönetici, 2015). Örgütsel adalete yönelik olarak çalışanların daha çok terfi sürecinde yapılan adam kayırmacılık, maaş skalasının dengesiz dağılımı, terfi ve yükselmelerin performans gözetilmeksizin yönetici inisiyatifine bırakılması gibi hususlar göze çarpmaktadır. Bu bağlamdaki çalışan deneyimine ilişkin bir görüşe aşağıda yer verilmiştir:

- "Çalışmak isteyene arkasını dönen, referansı olduğu için iki lafi bir araya getiremeyen birçok insana iş imkân verip her şeyi yapan insanları işten çıkaran, samimiyetsiz, verdiği sözlerde durmayan hak yiyen bir bankadır." (Denizbank Çalışanı, Tele-pazarlama, 2017). 


\section{Çalışanlarda İş Tatminsizliği Yaratan İş ile İlgili Faktörler}

Çalışanlarda iş tatminsizliği yaratan iş ile ilgili faktörler; terfi imkânının olmamasl, iş yükünün fazla olması, performans değerlendirme sistemindeki problemler, hedef ve satış baskısının olması, iş yaşam dengesinin gözetilmemesi, kariyer geliştirme ve eğitim imkânlarının yetersizliği olarak sıralanmıştır. Terfi imkânlarına yönelik genel olarak terfi sürelerinin uzun olması, gösterilen performansın yüksek olmasına karşın hak edilen terfiinin alınamaması gibi hususlar ifade edilmiştir. Bu noktada paylaşılan çalışan yorumların biri şu şekildedir:

- "Tek sorun alt kademeden başlandığında yükselmek çok zor. Bir üst kademeye geçme hakk elde etseniz dahi talebin çok olduğu şehirlerde uzun süre yükselmeyen çalışanlar meocut." (Garanti Bankası Çalı̧anı, Kurumsal Satış Temsilcisi, 2014)

Konulan satış kotalarının yüksek olması, yükselme ve maaşların bu satış hedeflerine bağlı olması, çalışanların işleriyle ilgili memnuniyetsizlik duyduğu bir diğer noktadır. Öyle ki satış hedefleri ile baş edemeyen çalışanların etik dışı yöntemlere başvurduğu bir çalışanın yorumuna şu şekilde yansımıştir:

- "Satış yoksa hiç olduğun, bütün bilgi ve donanımın ve o ana kadar yaptıklarının yok sayıldı̆̆̆, baskıdan etik olmayan satış yöntemlerine yönelen mutsuz ve psikolojisi bozulmuş, stresli, gerilimli personelin kurum aidiyet duygusunu kaybetmiş varllğı ve bu durumun uzun dönem için banka ve çalışanlar adına oluşturduğu olumsuz etki." (Akbank Çalışan, Gişe Yetkilisi, 2018)

Performans değerlendirme sisteminde ise adalet konusunda zafiyet olduğu ve değerlendirmelerin sadece bağlı olunan yönetici tarafından yapıldığı ifade edilmiştir. İş yaşam dengesi noktasında çalışanlar iş yoğunlukları dolayısıyla kendilerine, aile ve sosyal yaşamlarına zaman ayıramadıklarını belirtmiştir. Bunun yanı sıra Eğitim ve Kişisel Gelişim imkânlarının yetersizliği, kariyer anlamında çalışanların önünü açmaya yönelik faaliyetlerin kısıtlı olduğu ifade edilmiştir.

\section{Çalışanlarda İş Tatminsizliği Yaratan Psikolojik Faktörler}

Çalışanlarda iş tatminsizliği yaratan psikolojik faktörler arasında iş stresinin fazla olması, mobbing ve çalışanlara değer verilmemesi gibi hususlara yer ve- 
rilmiştir. Çalışanlara değer verilmemesi noktasında genel olarak çalışan fikirlerinin dikkate alınmadığı, çalışandan çok işin önemli olduğu bir anlayışın hâkim olduğu saptanmıştır. Bunun yanı sıra çalışanlar çok fazla iş stresi yaşadıklarını belirtmiştir. Çalışanlardan biri bu stresin kaynağını şu şekilde açıklamıştır:

- "Rahat çalışma imkânı sunulmadığı için baskı altında ve verilen hedefler üzerinden sürekli hatırlatma yapılması stres yaratıyordu." (Garanti Bankası Çalışanı, Alacak Tahsilat Uzmamı, 2017)

Son olarak çalışanlar mobbinge maruz kaldıklarına değinmişlerdir. Bu bağlamda yapılan çalışan yorumlarından biri aşağıda yer almaktadır:

- "Bir müşteri şikâyet etmişti beni ve teftişlik olmuştum. Sonradan müşteri benim şikâyetimi geri çekmiş. Normalde isten atmaları lazım ama beni eşek gibi 5 ay daha çalıştırdılar. Ve o çalıştırdıkları dönemde her an atabiliriz diye dalga geçerek korkutmaya çalışıyorlard. Neyse ki ben gerekli kişilere ulaştım ondan sonra şikâyetin geri çekildiğini ama bana hiçbir şekilde bu durumdan bahsetmediklerini başka bir durumda bunu koz olarak kullanacakların öğrendim." (Garanti Bankası Çalışanı, Müşteri Temsilcisi, 2018)

\section{Çalışanlarda İş Tatminsizliği Yaratan Çalışma Koşullarn}

Fiziksel ortam yetersizliği, çalışma ortamı ve iş yerinin lokasyon olarak uzaklığı, çalışanlarda iş tatminsizliği yaratan çalışma koşulları arasında yer almaktadır. Çalışanlar genel olarak yorumlarında çalışma ortamlarının gergin ve sıkıcı olmasının yanı sıra donanım anlamındaki yetersizliklere değinmişlerdir. Fiziksel ortamın yetersizliğine dair bir çalışanın görüşü şu şekildedir:

- "Kendine ait genel müdürlük binasinda çalışanlarm faydalanabileceği bir spor salonu dahi bulunmamakta. Ayrica yine genel müdürlük binasında çalışanlarm mola verebileceği alanlar ve düzgün bir kafeterya bulunmamakta." (Şekerbank Çalışanı, Genel Müdürlük, 2019)

\section{Çalışanlarda İş Tatminsizliği Yaratan Bir Unsur Olarak Ücret ve Yan} Haklar

Alınan ücretin yetersizliği, prim, mesai ücretleri gibi ödemelerdeki problemler, maaşlara yapılan zammın yetersizliği ve yan hakların azlığ 1 ücret ve yan haklar konusunda tatminsizlik yaratan unsurlar arasında yer almıştır. 
Çalışanlar, kurularında ücret artış ve yan hak politikası olmaması sebebiyle maaş artışlarının hangi ayda olacağını bilmedikleri gibi bazı yıllarda zamların yapılmadığını ifade etmiştir. Ücret anlamında ise alınan ücretin yapılan iş, yaşanılan strese karşın düşük düzeyde kaldığı belirtilmiştir. Bunun yanı sıra rakip bankalarla kıyaslandığında da maaş düzeylerinin düşük kaldığı şe şekilde ifade edilmiştir:

- "Yoğun çalışma saatleri (en az 12 saat) tüm dikkat ve özen ile çalışılmasına rağmen hak edilen maaş verilmemektedir." (Denizbank Çalışanı, Operasyon Yönetmeni, 2017)

Prim ödemelerindeki problemler ise bir çalışanın yorumunda "Prim olayı da aynı şekilde, çoğunlukla prim/temettü verilmiyor. Uzun vadede enflasyon karşısinda geliriniz önemli oranda eriyor." (Şekerbank Çalşanı, Genel Müdürlük, 2019) şeklinde ifade edilmiştir.

\section{Çalışanlarda İş Tatminsizliği Yaratan Bir Unsur Olarak Çalışma Hayatın- daki İlişkiler}

Çalışma hayatındaki ilişkiler açısından değerlendirildiğinde iş arkadaşları ile olan ilişkiler, yöneticilerin çalışanlarla ilişkileri ve müşterilerle ilişkiler göze çarpmaktadır. İş arkadaşları noktasında çalışanlar iş yoğunluğu nedeniyle sosyal etkileşimin az olduğundan ve herkesin genel olarak işine odakland1ğından bahsetmiştir. Örneğin; Halkbank çalışanının ifadesi şu şekildedir:

- "Müşterilere çok iyi davranılması bir artı olsa da birbirlerine aynı şekilde yaklaşmamaları çalışma ortamını çok zor ve çekilmez hale getiriyor." ( Halkbank Çalışanı, Servis Görevlisi, 2016).

Yöneticilerle olan ilişkilerin resmi olduğu ve satış hedeflerinin gerçekleşmesi odaklı olduğu ifade edilmiştir. Çalışanlar yorumlarında, yapılan iş sonucu takdir göremediklerine de yer vermiştir. Öte yandan yöneticilerin çal1şanların usulsüz uygulamalara yönettiği de bir çalışan yorumunda şu şekilde belirtilmiştir: "Son yöneticim usulsüz işlemler yaptı̆̆ı ve yaptırmaya zorladığı için ayrılmak durumunda kaldım." (Şekerbank Çalışanı, Yetkili, 2018) 


\section{Çalışanlarda İş Tatminsizliği Yaratan Bir Unsur Olarak Çalışma Saatleri-} nin Fazlalı̆̆

Vardiyaların çokluğu, mola sürelerinin kısa olması, hafta içi ve hafta sonu mesailerinin fazlalığı ve hafta sonuna konulan toplantılarının çalışanlarda tatminsizlik yarattığı saptanmıştır. Bu bağlamda yapılan bir yoruma aşağıda yer verilmiştir:

"Tam anlamıyla rezalet. 9-6 vardiyası diye insann gözünü boyuyorlar. Sabah 8'de servis binaya bırakıyor çalışanları. Artık kaçta çıkabilirseniz takım liderinden izin alı." ( Denizbank Çalışanı, İletişim Merkezi Çalışanı, 2019)

\section{Temalara Göre Memnuniyetsizlik Yorumlarının Dağılımı}

Çalışanların en fazla ve en az memnuniyetsizlik duydukları tema ve alt temaları belirlemek amacıyla memnuniyetsizlik yorumlarının dağılımı incelenmiştir.

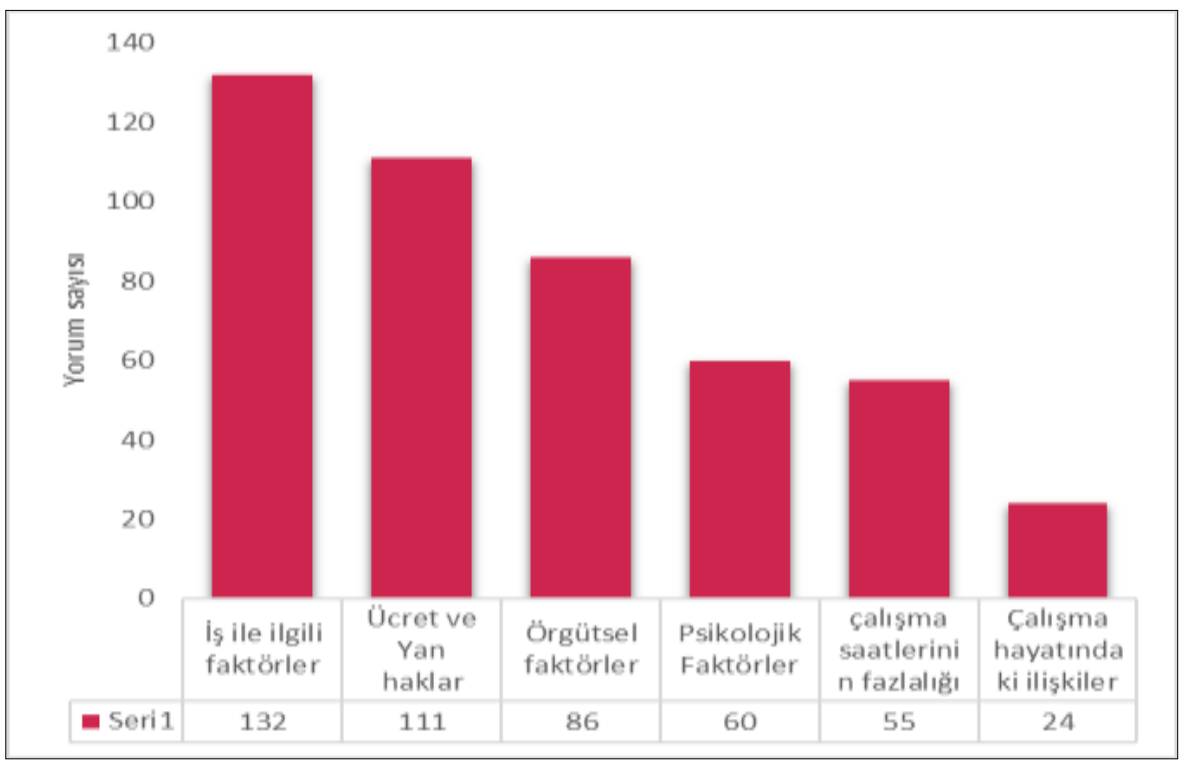

Şekil 1. Temalara Göre Memnuniyetsizlik Yorumlarmın Dağılımı 
Temalar bağlamında değerlendirildiğinde çalışanların en fazla işle ilgili faktörlerden memnuniyetsizlik duydukları belirlenmiştir. En az memnuniyetsizlik duydukları tema ise çalışma hayatındaki ilişkilerdir. Daha kapsamlı olarak sonuçların değerlendirilmesi için memnuniyetsizlik yorumlarının alt temalara göre dağılımı da incelenmiştir.

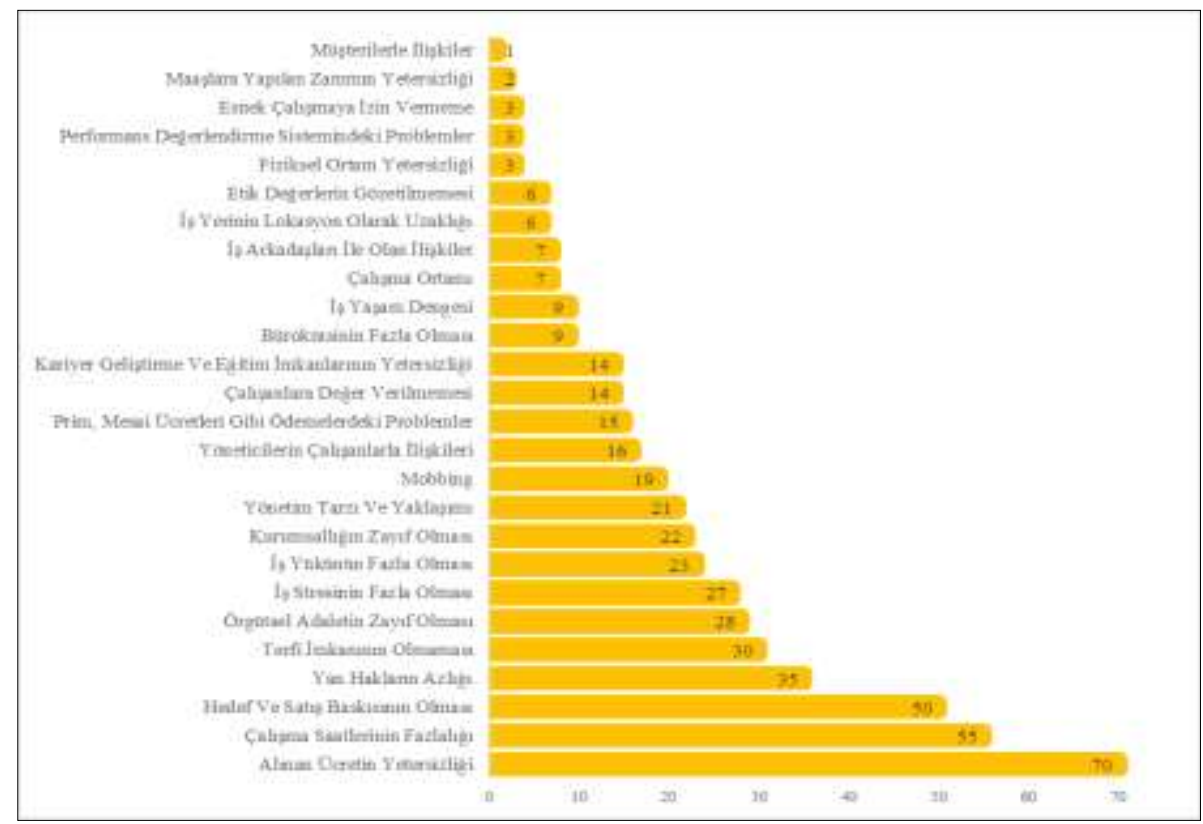

Şekil 2. Alt Temalara Memnuniyetsizlik Yorumlarının Dă̆ılımı

Alt temalar bazında değerlendirildiğinde; bankacılık sektörü çalışanların en fazla alınan ücretin yetersizliği konusunda tatminsizlik yaşadığı görülmektedir. Çalışma saatlerini fazlalığı ve hedef ve satış baskısının olması ücretten sonra en fazla memnuniyetsizlik yaratan diğer unsurlardır. Öte yandan çalışanların en az tatminsizlik yaşadığı noktanın müşterilerle ilişkiler olduğu görülmektedir. 


\section{Çalışan Yorumlarnnda Kamu ve Özel Sektör Karşılaştırması}

Çalışanların memnuniyetsizlik yorumlarının kamu ve özel sektör bağlamında dağılımındaki benzerlik ve farklılıkları saptamak amacıyla, yorumlar üzerinden sektörel bir karşılaştırma yapılmıştır.

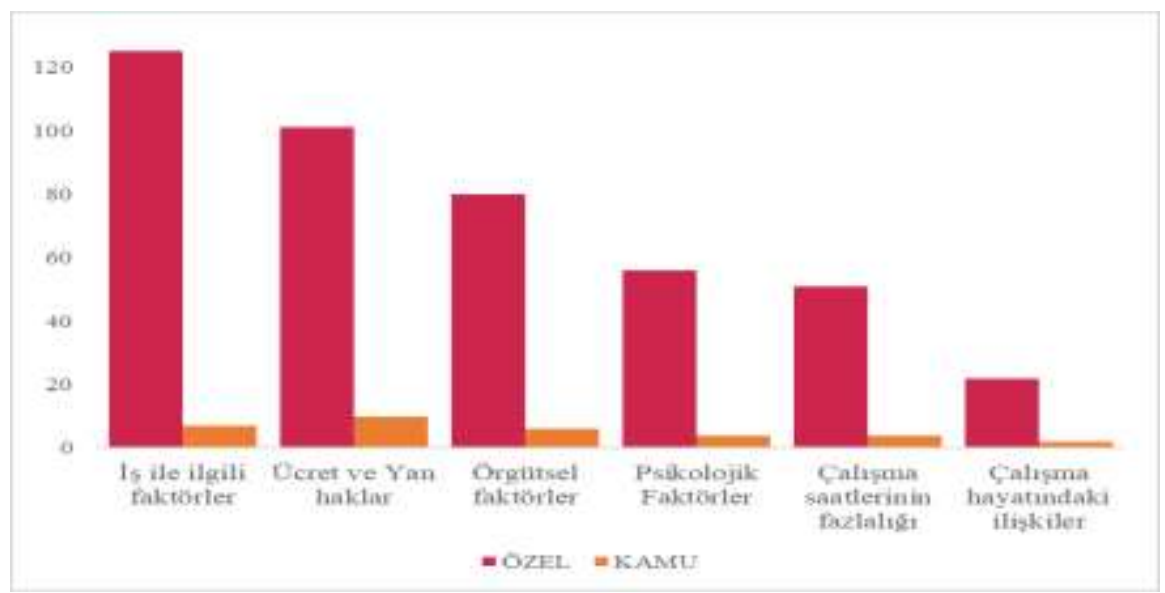

Şekil 3: Kamu ve Özel Sektöre Göre Memnuniyetsizlik Yorumlarnnın Dağılımı

Bu bağlamda kamu sektöründe çalışanlar en fazla genelde işle ilgili faktörler teması ve özelde alınan ücretin yetersizliği alt teması bağlamında memnuniyetsizlik duyarken, kamu sektörü çalışanları ücret ve yan haklar teması ile yan hakların azlığı alt teması konusunda memnuniyetsizlik duymaktadır.

\section{Tartışma ve Sonuç}

Teknolojide ve internet kullanımında yaşanan gelişmeler; kurumlar için müşterileri, çalışanları, potansiyel çalışan adayları ve diğer paydaşlar ile etkileşim kurabilecekleri yeni bir platform açmıştır. Bu platformlarda kurumlara dair yapılan paylaşımlar, gerek tüketici gerekse çalışan ayağında sağlanan ürün ve hizmetler ve çalışma deneyimi gibi unsurlara dair görüşleri içermesi bakımindan kurumlar tarafından üzerinde durulması gereken bir husustur.

$\mathrm{Bu}$ bağlamda bu çalışma, bir işveren değerlendirme sitesi olan Indeed.com web sitesinden toplanan veriler kullanılarak, nitel araştırma tasa- 
rımı ile daha detaylı ve kapsamlı sonuçlar elde edilmesi amaçlanmıştır. Online çalışan yorumları, çalışanların işlerine karşı tatminsizlik duydukları faktörler bağlamında farklı bir bakış sunmuştur. Elde edilen bulgulara göre bankacilık sektörü çalışanlarının ücret ve yan haklar, iş ilişkileri, çalışma koşulları, çalışma saatleri, örgütsel faktörler, psikolojik faktörler ve iş ile ilgili çeşitli faktörlerden memnuniyetsizlik duyduğu belirlenmiştir. Buna ek olarak bankacilık sektörü çalışanlarının en fazla «ücret ve yan haklar» ve «iş ile ilgili faktörler» temalarından memnuniyetsizlik duyduğu belirlenmiştir. Bunun yanı sıra, «alınan ücretin yetersizliği», «satış ve hedef baskısının olması» ve «çalışma saatlerinin fazla olması» en fazla memnuniyetsizlik yaratan alt temalar arasında yer almaktadır. Sektör bazında karşılaştırıldığında; kamu sektöründe çalışanlar en fazla «ücret ve yan haklar» konusunda memnuniyetsizlik duyarken özel sektör çalışanları «iş ile ilgili faktörler» den memnuniyetsizlik duymaktadır.

Yöneticiler ve kurumlar açısından değerlendirildiğinde; çalışanların kurumları ve işlerine dair fikir, görüş ve problemlerini paylaştıkları bu yeni platformları etkin bir şekilde kullanan kurum ve yöneticiler rekabet avantajı elde etmede önemli bir firsat elde edecektir. Çalışanların sosyal medya platformlarında kurumlarına dair yapacakları olumlu yorum ve paylaşımlar kurumların kurumsal marka imajını geliştirmesine olanak tanıacaktır. Olumsuz mesaj ve içerikler ise kurumların geleneksel kurumsal iletişim kanalları ile tespit edemedikleri konuların fark edilmesi açısından önemlidir. Memnuniyetsizlik paylaşımlarının altında yatan nedenlerin doğru bir şekilde belirlenmesi ve bu durumları ortadan kaldıracak faaliyetlerin gerçekleşmesi de potansiyel işten ayrılmaların önüne geçilmesini sağlayacaktır.

Araştırma bulgularına göre; bankacllı sektörü yöneticilerinin özellikle ücret ve yan haklar konusunda iyileştirmeler yapmaları gerektiği görülmektedir. Buna ek olarak satış noktasında yapılan baskıların azaltılması ile çalışanlarda yapılan işlerin kendilerinden daha önemli olduğu hissiyatının yok edilmesi gerekmektedir. Çalışma saatlerinin azaltılması ya da mesailerin planlı bir şekilde gerçekleştirilmesi ile de çalışanların iş ve özel yaşam dengeleri sağlanarak iş tatmin düzeyleri yükseltilebilecektir.

Son olarak, araştırmanın çalışanların sosyal medya araçları ile paylaştıkları görüş ve düşüncelere odaklanan kısıtlı çalışma alanına katkıda bulunması beklenmekte, uygulayıcılar açısından ise bu platformlarda yer alan yorumlara dair genel ve sistematik bir bakış sunması beklenmektedir. 


\section{Kısıtlar ve Gelecek Çalışma Önerileri}

Araştırma örneklemi sadece Türkiye'deki bankacılık sektörü çalışanlarının Indeed.com web sitesinde yaptığ 1 yorumlardan oluşmaktadır. Gelecek araştırmalarda farklı sektörlerin karşılaştırmalı olarak incelenmesi faydalı olacaktir.

Indeed.com web sitesi üzerinde 60 ülke çalışanlarının verilerinin bulunması sebebiyle ülkeler ve kültür bazlı karşılaştırmalı incelemeler faydalı olacaktır. Bunun yanı sıra araştırmaya konu olan veriler işveren değerlendirme sitelerinden Indeed.com üzerinden alınan verilerden oluşmaktadır. Gelecek araştırmalarda diğer işveren değerlendirme sitelerinden alınan verilerin de kullanılması sonuçların genellenebilirliği ve örneklemin evreni temsil edebilme gücünü arttıracaktır. Bunun yanı sıra gelecek çalışmaların Twitter gibi farklı sosyal medya kanallarından elde edilen verilerle desteklenmesi faydalı olacaktır.

Bu araştırma kapsamında yöntem olarak sadece içerik analizinden faydalanılmıştır. Gelecek araştırmalarda bankacılık sektörü çalışanlarıyla mülakat yöntemi ile gerçekleştirilebilecek bir çalışma, iş tatminsizliğinin nedenlerini belirlemekle kalmayıp, çalışan davranışlarını nasıl etkilediği üzerinde daha kapsamlı bulgular elde edilebilmesi mümkündür. 


\title{
EXTENDED ABSTRACT
}

\section{\#I(dont)lovemyjob: A Content Analysis On Online Reviews of Employees in the Banking Sector}

\author{
Berivan Tatar - Büşra Müceldili - Oya Erdil \\ Gebze Technical University
}

With the widespread use of the internet, employees had the opportunity to share information about their organizations through new communication channels. In addition to social media channels, employer evaluation sites have provided employees with a new environment in which they can share their ideas, opinions, and concerns.

It is known that using the traditional communication channels within the organization is not preferred to share the points that the employees see as problematic because of the fear of being fired and in this case the employees generally prefer to remain silent (Morrison, 2014, p.180-184). In contrast to traditional communication channels, blogs used in word of mouth communication in electronic media provide anonymous sharing in employer evaluation sites and social networks and can be preferred more because employees reduce the anxiety in traditional word of mouth communication. In addition, it was determined that the shares of employees about their organizations in social media affect the perception of the corporate image of potential employees and have an effect on the intention of these candidates to apply for work (Van Hoye and Lievens, 2009, p.349). When evaluated in terms of existing employees; the content of shared messages is an important resource that can help organizations to understand the points where their employees are satisfied or not.

However, it is observed that the studies remain limited in the management perspective, word-of-mouth communication literature (Van Hoye and Lievens, 2009, p.341), and the word-of-mouth communication in social networks (Keeling, McGoldrick and Sadhu, 2013, p.100). In this context, the aim of this study is to provide an overview for the organizations by identifying the issues of dissatisfaction of the employees in the banking sector where the turnover rates are high, based on the secondary data received from the Indeed.com website. 
Employee reviews on Indeed.com were used as secondary data in order to determine the employees' dissatisfaction with their organizations. Indeed.com is available in 28 languages in more than 60 countries, with 150 million company reviews and 600 million salary information. Indded.com is a website where employees can share their experiences in their organizations anonymously.

In this study, 613 comments made by the employees of 19 banks on Indeed.com were subjected to content analysis. 120 of these comments were made by interns and these reviews excluded with the thought that interns have not enough experience to evaluate the organization due to short periods of work. As a result, content analysis was conducted on a total of 484 comments were made between 2012 and 2019.

Conway et al. (2019, p.7), the themes of psychological and organizational factors emerged in addition to the themes in this study. In order to reduce the bias of research, all the researchers in the coding process created separate code lists based on the comments, and then came together to discuss the similar and different codes to form the final code list. At the end of the coding process, 7 main themes and 25 sub-themes were presented.

According to the findings, it was determined that the banking sector employees were dissatisfied with various factors related to wages and benefits, working relationships, working conditions, working hours, organizational factors, psychological factors, and job-related factors. Evaluated in terms of themes, it was found that employees were most dissatisfied with job-related factors. The least dissatisfied theme is the relationships in working life. The distribution of dissatisfaction comments by sub-themes was also examined in order to evaluate the results more comprehensively and It is seen that the banking sector employees are most dissatisfied with the insufficiency of the wages. Excessive working hours and workload and sales pressure are the other factors that create dissatisfaction. On the other hand, it is seen that employees experience the least dissatisfaction is the relations with the customers.

Additionally, while public sector employees are mostly dissatisfied with the theme of work-related factors and in particular the sub-theme of insufficiency of wages, public sector employees are dissatisfied with the theme of wages and benefits and the lack of fringe benefits. 
Using new social media platforms in which employees share their ideas, opinions, and problems related to their organizations and businesses effectively, organizations and managers will gain an important opportunity and competitive advantage. Employees' negative reviews and contents are important for recognizing the issues that organizations cannot identify through traditional corporate communication channels. Correctly identifying the underlying causes of dissatisfaction and conducting activities to eliminate these situations will also help for preventing potential layoffs.

\section{Kaynakça / References}

Alrubaian, M., Al-Qurishi, M., Alamri, A., Al-Rakhami, M., Hassan, M. M. ve Fortino, G. (2018). Credibility in online social networks: A survey. IEEE Access, 7, 2828-2855.

Conway, E., Rosati, P., Monks, K. ve Lynn, T. (2019). Voicing job satisfaction and dissatisfaction through Twitter: employees' use of cyberspace. New Technology, Work and Employment, 34(2), 139-156.

Goes, P. B., Lin, M. ve Au Yeung, C. M. (2014). "Popularity effect” in user-generated content: Evidence from online product reviews. Information Systems Research, 25(2), 222-238.

Griffeth, R., Hom, P. W. ve Gaertner, S. (2000). A Meta Analysis Antecedents and Between Employee Turnover. Journal of The Management, 26(3), 463-488.

Guba, E. G. ve Lincoln, Y. S. (1982). Epistemological and methodological bases of naturalistic inquiry. Educational Communication \& Technology, 30(4), 233252.

Hirschman, A. O. (1970). Exit, voice, and loyalty: Responses to decline in firms, organizations, and states. Harvard university press.

Iaffaldano, M. ve Muchinsky, P. (1985). Job satisfaction and Job Performance. American Psychological Association Inc., 97(2), 251-273.

Keates, N. (2007). Deconstructing tripadvisor. Wall Street Journal, 1(4).

Keeling, K. A., McGoldrick, P. J., Charavitsidou, P. ve Thompson, H. (2015). Swom: A Delphi study of the content and valence of staff word of mouth. In Marketing in Transition: Scarcity, Globalism, \& Sustainability (pp. 378-378). Springer, Cham.

Keeling, K. A., McGoldrick, P. J. ve Sadhu, H. (2013). Staff Word-of-Mouth (SWOM) and retail employee recruitment. Journal of Retailing, 89(1), 88-104. 
Kemp, S. (2019). Digital 2019: Global internet use accelerates. 25 Ekim 2019 tarihinde https://wearesocial.com/blog/2019/01/digital-2019-global-internetuse-accelerates adresinden erişildi.

Lam, T. ve Qiu Zhang, H. (2003). Job satisfaction and organizational commitment in the Hong Kong fast food industry. International Journal of Contemporary Hospitality Management, 15(4), 214-220.

Luca, M., \& Zervas, G. (2016). Fake it till you make it: Reputation, competition, and Yelp review fraud. Management Science, 62(12), 3412-3427.

Melián-González, S. ve Bulchand-Gidumal, J. (2016). Worker word of mouth on the internet: Influence on human resource image, job seekers and employees. International Journal of Manpower, 37(4), 709-723.

Milliken, F. J., Morrison, E. W. ve Hewlin, P. F. (2003). An exploratory study of employee silence: Issues that employees don't communicate upward and why. Journal of Management Studies, 40(6), 1453-1476.

Morrison, E. W. (2014). Employee Voice and Silence. Annual Review of Organizational Psychology and Organizational Behavior, 1(1), 173-197.

O'connor, P. (2010). Managing a hotel's image on TripAdvisor. Journal of hospitality marketing \& management, 19(7), 754-772.

Silva, P. (2006). Effects of disposition on hospitality employee job satisfaction and commitment. International Journal of Contemporary Hospitality Management, 18(4), 317-328.

Van Hoye, G. ve Lievens, F. (2009). Tapping the Grapevine: A Closer Look at Wordof-Mouth as a Recruitment Source. Journal of Applied Psychology, 94(2), 341352.

Wandelt, M. A., Pierce, P. M. ve Widdowson, R. R. (1981). Why nurses leave nursing and what can be done about it. The American journal of nursing, 72-77.

\section{Kaynakça Bilgisi / Citation Information}

Tatar, B., Müceldili, B. ve Erdil, O. (2020). \#İşimisev(m)iyorum: Banka sektöründe çalışanların online yorumları üzerine bir içerik analizi. OPUS-Uluslararası Toplum Araştırmaları Dergisi , 16(27), 465-489. DOI: 10.26466-/opus.642768 